\title{
TCL1B wt Allele
}

National Cancer Institute

\section{Source}

National Cancer Institute. TCL1B wt Allele. NCI Thesaurus. Code C52139.

Human TCL1B wild-type allele is located in the vicinity of 14 q32.1 and is approximately 30 $\mathrm{kb}$ in length. This allele, which encodes $\mathrm{T}$-cell leukemia/lymphoma protein $1 \mathrm{~B}$, may be involved in the modulation of embryogenesis, cell survival and cellular proliferation. The wild-type allele is expressed at elevated levels in T cell leukemias. 